\title{
Examination of Sustainable Water Management at Norway's Major Hub Airport: The Case of Oslo Airport Gardermoen
}

\section{Glenn Baxter *}

School of Tourism and Hospitality Management, Suan Dusit University, Huahin Prachaup Khiri Khan, Thailand, 77110; E-Mail: g glennbax@dusit.ac.th

* Correspondence: Glenn Baxter; E-Mail: g_glennbax@dusit.ac.th

Academic Editor: Zed Rengel

Adv Environ Eng Res

2021, volume 2, issue 4

doi:10.21926/aeer.2104034
Received: October 22, 2021

Accepted: December 06, 2021

Published: December 15, 2021

\begin{abstract}
The present study used a detailed qualitative longitudinal research approach to examine the trends of water consumption, wastewater volumes, and drainage water volumes in Oslo Airport Gardermoen, which is Norway's major hub airport, between the years 2005 and 2020. An overall upward trend was observed in the water consumption at Oslo Airport Gardermoen, which was consistent with the growth in air traffic and aircraft movements during the study period. The annual water consumption per enplaned passenger was observed to fluctuate during the study period. While the lowest water consumption per passenger ( 8 liters per passenger) was recorded in 2008, the highest levels (14.6 liters per passenger) were recorded in 2020. The annual water consumption (cubic meter per aircraft movement) increased during the study period, which was consistent with the growth in aircraft movements and the use of larger aircraft. The annual wastewater volume generally increased during the study period, while the annual drainage water volume fluctuated remarkably during the study period, with the latter reflecting varying drainage patterns at the airport. Oslo Airport Gardermoen has implemented a range of sustainable water management practices to supplement its existing water management practices and policies.
\end{abstract}

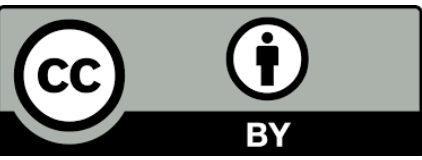

(C) 2021 by the author. This is an open access article distributed under the conditions of the Creative Commons by Attribution License, which permits unrestricted use, distribution, and reproduction in any medium or format, provided the original work is correctly cited. 


\section{Keywords}

Airports; case study; Oslo airport Gardermoen airport; sustainable water management; water consumption; wastewater

\section{Introduction}

Airports play a vital role in the global air transport value chain by serving as the critical interface point between the land-based and air transport modes. It is the landside and airside infrastructure of the airports that enables the key actors, including airlines, ground handling staff, and air traffic management, to efficiently deliver passenger and air cargo services [1, 2]. However, significant quantities of water are required to maintain the infrastructure for delivering such services [3-5], because of which water consumption is very large at the airports. In addition, wastewater is produced in large quantities at airports [6]. In view of the adverse impact these two could have on the environment, airports around the world are seeking to establish and implement sustainable water management strategies and policies $[7,8]$.

The global air transportation industry includes a large diversity of airports for facilitating the movement of air traffic. Examples of the various kinds of airports include rural airstrips, military airports, regional community airports, regional airports, major city airports, and major hub airports [9]. The present study focused on the major hub airports. The main objective of the present study was to empirically examine the water consumption at Oslo Airport Gardermoen, which is the largest airport in Norway. In addition, Oslo Airport Gardermoen is a major Scandinavian hub airport. Another objective of the present study was to examine how the increased passenger traffic and aircraft movements have influenced water consumption at Oslo Airport Gardermoen during the study period. Moreover, the annual drainage and wastewaters generated each year at Oslo Airport Gardermoen were evaluated. Finally, the sustainable water management practices implemented by the airport, which could justify its water management, were identified. Oslo Airport Gardermoen was particularly selected as the case airport as it is a major Scandinavian hub airport that is served by both full-service network carriers (FSNCs) and low-cost carriers (LCCS). Moreover, the airport has demonstrated committed sustainable operations throughout its history. The availability of a comprehensive dataset covering the period between 2005 and 2020 was another factor for selecting the Oslo Airport Gardermoen as the case airport.

The remainder of the manuscript is organized as stated ahead. The review of the literature describing the context of the case study is presented in Section 2. The research methodology used for the case study is presented in Section 3. The details of the Oslo Airport Gardermoen case study are presented in Section 4. The findings of the case study are provided in Section 5.

\section{Background}

As stated previously, airports consume substantial volumes of water to maintain their infrastructure and operations [3, 4, 6, 8]. Airport operators, ground service providers, passengers, and staff require water for various purposes, such as drinking, catering, retail, cleaning, flushing toilets, system maintenance, and maintenance and landscaping of the airport grounds [10]. 
Moreover, the run-off water from the operational area of an airport is a significant environmental threat as wastewater exerts a negative impact on both soil and groundwater owing to its relatively high concentration of contaminants [11]. Wastes associated with aircraft refueling, operations, and cleaning might enter the lakes and streams located in the vicinity of the airport via the stormwater drainage system of the airport. Other operational activities at the airport may also influence water quality through contaminants in stormwater run-off, such as major aircraft overhauls that use toxic chemicals to remove paint ([12], p. 732). The contaminants originating from different operations and activities undertaken at airports include detergent formulations, solids, oils, greases, residues, solvent residues, and heavy metals [13]. Grease and detergent contamination of the wastewater generated at an airport is also contributed by the discharge of the fire-fighting foam deployed during an aircraft emergency [14], and the preparation of the meals served in the flight and the restaurants and staff canteens at the airport [8].

The wastewaters generated from the paved areas of the airport, particularly from the apron areas, could be sent for treatment to a special treatment facility located at the airport, where the oil products would be separated from the wastewater. Alternatively, a collector could be connected to a local municipal treatment plant. Fuel storage and maintenance facilities for aircraft hangars, aircraft, and ground service equipment (GSE) should be equipped with suitable traps for waste oil products. Moreover, such facilities should be inspected regularly [15].

With the increasing pressure to reduce water consumption and conserve the available water resources at airports, it is imperative that the activities and operations undertaken at the airports are managed in a manner directed toward reducing the overall water consumption. In addition, the surface water and groundwater resources at the airports have to be managed better [10]. In order to achieve these environment-related sustainability objectives, several airports around the world have adopted and implemented a range of initiatives for water management [16]. These initiatives include an overall reduction in water consumption $[8,17]$, treatment of wastewater and sewage discharge water in treatment plants and then using the treated water in toilet facilities and for irrigation $[6,8,18]$, the use of rainwater in toilets flushes in airport buildings and facilities $[6,8,19]$, protection of the groundwater in the airport precinct from pollution [20], monitoring of the overall water consumption at the airport [21], and regular evaluation of the quality of surface water and groundwater at the airports $[6,8,10,22]$. Greywater reuse has emerged as an ideal alternative for reducing potable water consumption in commercial buildings at airports. In summary, airports, owing to their large terminal buildings and other related facilities, exhibit great potential for greywater utilization [23].

\section{Methods}

\subsection{Research Methodology}

In order to achieve the objectives of the present study, a longitudinal case study design was adopted for conducting the qualitative analysis of the detailed case study [24-26]. The key advantage of a qualitative longitudinal research design is that the study reveals the changes and growth in the outcome over a defined period [27]. Moreover, a case study design allows exploring complex phenomena [28, 29]. Qualitative case studies enable the collection of rich, explanatory information that provides deep insights into the phenomenon that is being studied [30]. Another 
advantage of a case study design is that it enables the researcher(s) to connect with the real-world practices [31].

\subsection{Data Collection}

The qualitative data collected for the present study was obtained from Avinor AS annual environmental reports. Therefore, secondary data was utilized in the present study for investigating the research objectives. The case study analysis was performed according to the recommendations of Yin [29]. Accordingly, the present case study analysis involved the use of multiple sources of case evidence, storing and analyzing the collected data in a database concerning the study subject, and recording a series of case study evidence data obtained in the qualitative analysis.

\subsection{Data Analysis}

The collected qualitative data were subjected to document analysis. Document analysis focuses on the information and data available in the formal documents and company records, which have to be collected by the researcher(s) conducting the analysis [32-34]. The existing documents represent an important source of qualitative data. These data might be available publicly or could be private in nature [35]. Documents are one of the major forms of data sources for a case study research [36]. The documents collected for the present study were examined based on the following four criteria: authenticity, credibility, representativeness, and meaning [37-39].

The keywords "Oslo Airport Gardermoen environmental management policy", "Oslo Airport Gardermoen environmental management system", "Oslo Airport Gardermoen annual water consumption", "Oslo Airport Gardermoen annual wastewater volumes", "Oslo Airport Gardermoen annual drainage waters", and "Oslo Airport Gardermoen sustainable water management measures" were used in the database searches.

The document analysis was conducted in six distinct phases. The first phase involved planning the types of documentation required and ascertaining their availability for the study. The second phase was that of data collection, which involved sourcing the documents from Avinor AS and developing and implementing a scheme for managing the collected documents. In the third phase, the documents were examined to assess their authenticity and credibility to identify any potential bias in them. The fourth phase involved carefully examining the content of the collected documents to identify and record the key themes and issues. The fifth phase involved deliberation and refinement in identifying any difficulties associated with the documents, reviewing the sources, and exploring the content of the documents. In the sixth and the final phase, the analysis of the data was completed [40]. All examined documents were in English. Each document was examined carefully, and key themes were coded and recorded in the form of a case study [41].

\section{Research Results}

\subsection{Oslo Airport Gardermoen: An Overview}

In 1998, Oslo established a new airport at Gardermoen. Oslo Airport Gardermoen was, at that time, a redundant military airfield. This new airport replaced the compact Oslo Fornebu Airport [42, 43] as the capacity of this old airport was a restraining factor for accommodating the expected traffic 
growth in the future [44]. The new airport, together with the high-speed train and improved road system connecting the airport, cost almost NOK 20 billion (\$USD 3 billion) [42]. Currently, the Oslo Airport Gardermoen (OSL) is the major air traffic hub of Norway. This airport is currently being operated by Oslo Lufthavn AS, which was established in 1992 as a subsidiary of Avinor AS [45]. The airport is in the municipality of Ullensaker, which is approximately $47 \mathrm{~km}$ north of Oslo [46]. Oslo Airport Gardermoen occupies an area of 13 square kilometers, which includes two runways that are $2,950 \mathrm{~m}$ and 3,600 $\mathrm{m}$ in length, respectively. The airport has a total of 72 passenger gates (44 with aerobridges) and 7 gates (4 Code D and 3 Code F) located at the cargo terminals [47].

A new passenger terminal was opened at the airport in April 2017, which has expanded the airport's annual capacity to 32 million passengers [48]. The new terminal was constructed west of the existing terminal building and occupies an area of $117,000 \mathrm{~m}^{2}$. The new triangular-shaped pier termed 'Pier B' or 'North Pier' was constructed north of the existing terminal building and has a floor area of $63,000 \mathrm{~m}^{2}[49]$.

Figure 1 illustrates the growth in the domestic and international passenger traffic at Oslo Airport Gardermoen from the year 2005 to 2020. The global financial crisis of 2008 exerted an adverse impact on passenger travel, which caused a signficant decline in the annual number of enplaned passengers at Oslo Airport Gardermoen between 2008 and 2009. Fortunately, since 2010, both domestic and international passenger traffic has been increasing steadily (Figure 1). However, in 2020, the COVID-19 pandemic caused a large decline in economic activity throughout the world, which disrupted the supply and demand chain of the air travel market [50]. The airline industry has encountered several threats in its history, although none have been as drastic, rapid, and severe as the one caused by the COVID-19 pandemic [51]. The global coronavirus crisis has led to most countries implementing restrictive measures to confine the pandemic [52], and these restrictions have exerted an adverse impact on the airline passenger demand at Oslo Airport Gardermoen as international passengers comprise the largest proportion of the total number of enplaned passengers at Oslo Airport Gardermoen.

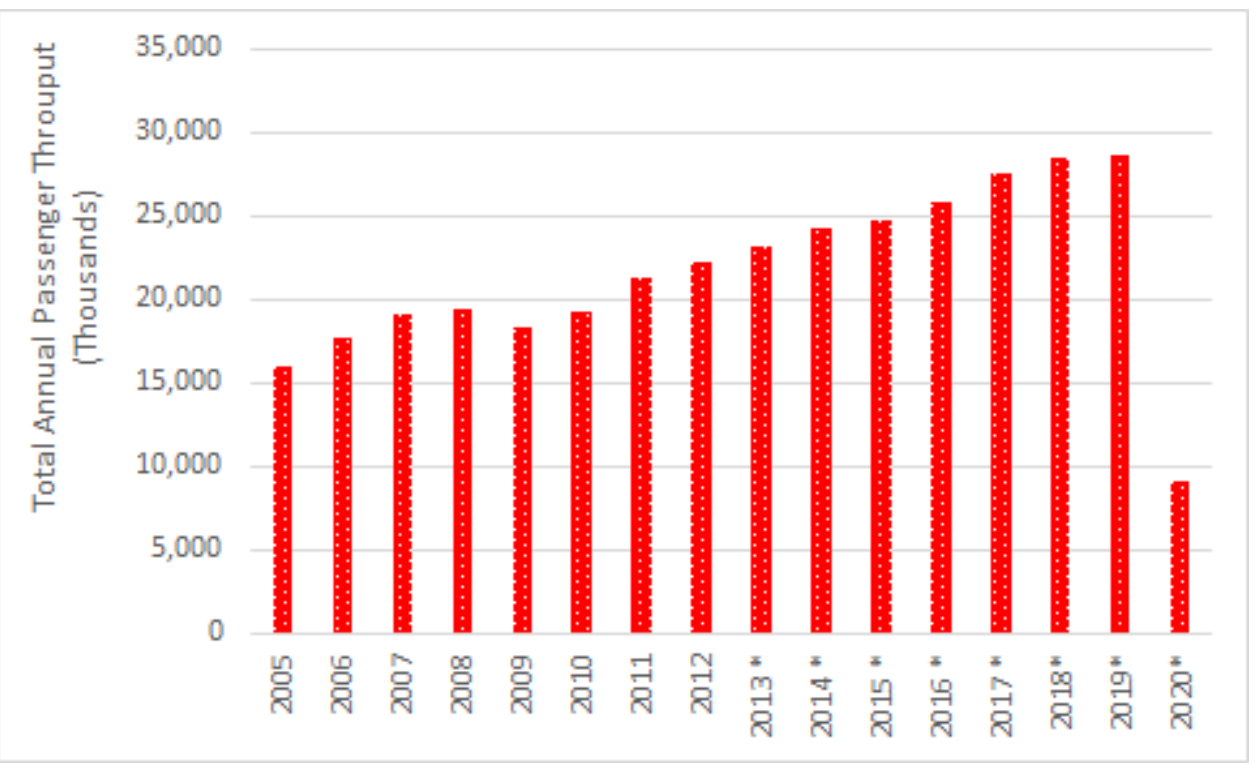

Figure 1 Total annual domestic and international enplaned passengers at Oslo Airport Gardermoen during 2005-2020. Note: Since 2013, the number of passengers included both scheduled and chartered passengers, including infants. Source [53]. 
Figure 2 illustrates the annual domestic and international aircraft movements at the airport between 2005 and 2020. Similar to the annual enplaned passenger traffic, the aircraft movements also exhibited a decline in 2009 because of the GFC, and then since 2010, a steady growth rate was observed. Again, in 2020, a marked decrease was observed in the aircraft movements at the airport because of the COVID 19 pandemic that impacted the airline aircraft fleet deployment in the whole world.

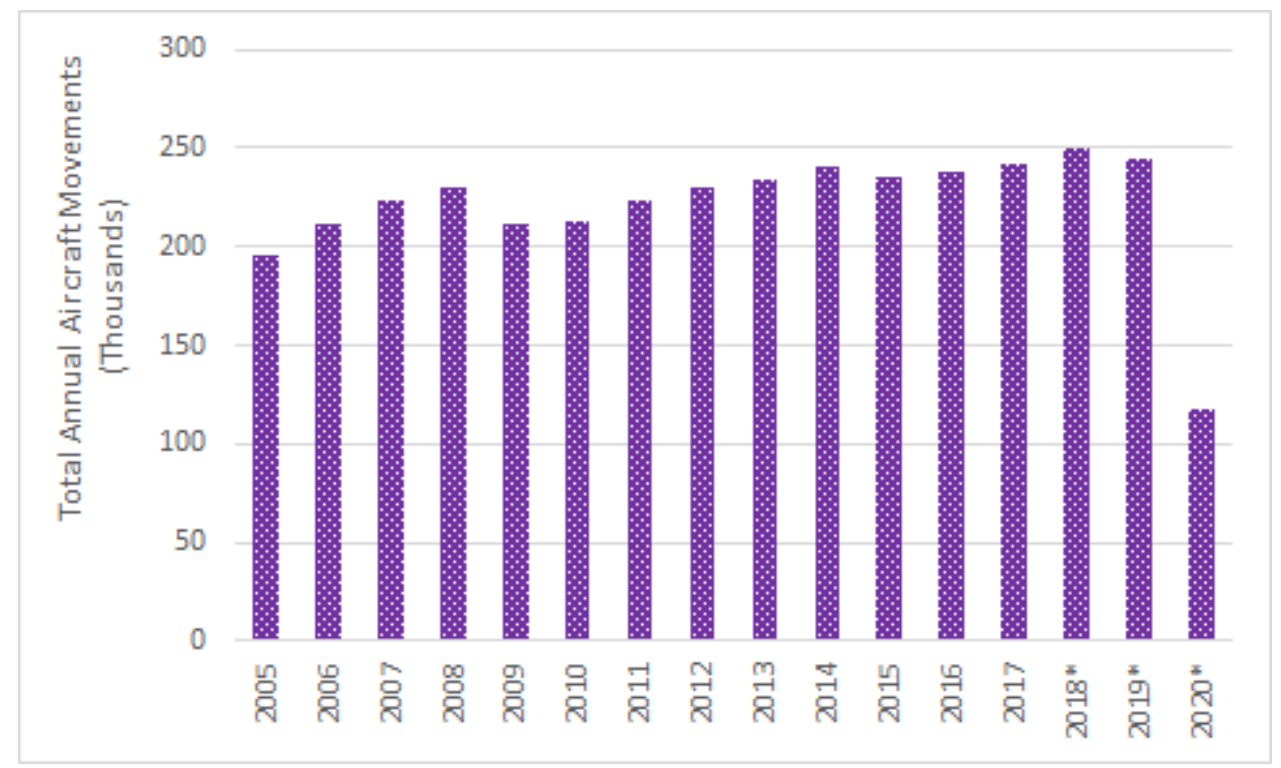

Figure 2 Total annual aircraft movements (domestic as well as international) at Oslo Airport Gardermoen during 2005-2020. Source [53].

\subsection{Environmental Policy at Oslo Airport Gardermoen}

As stated previously, Oslo Airport Gardermoen is managed and operated by Avinor AS. Avinor AS is a completely state-owned limited company under the Norwegian Ministry of Transport and Communications. Avinor AS is responsible for the management and operations of 44 state-owned airports in Norway [54]. Avinor AS has defined and implemented a policy that describes the general principles for environmental and social responsibility to be followed in the company. This policy aims to improve the environmental performance of Avinor and also to ensure that the company serves as a driving force for the environmental work in the aviation industry so that the company emerges as a leader in the field of corporate social responsibility in the Norwegian aviation industry ([55], p. 4).

The environmental principles described in the environmental policy of Avinor are as follows:

The company works to constantly improve its environmental performance and actively reduce the impact of the business on the environment.

The company necessitates complying with all the regulatory requirements and its own requirements. Accordingly, the environmental management practices of the company must align with the ISO14001 Environmental Management System to ensure a systematic approach to coordinating and following up with the environmental work.

The company must ensure a high degree of environmental awareness and expertise in the entire group. 
The employees and partners at the airports managed by Avinor AS must be aware of the significant environmental aspects of the Avinor Group.

The company must emphasize and integrate environmental considerations in the early stages of the planning and implementation of projects and when purchasing products and materials.

The company must place emphasis on the environment in its expansion projects.

The company aims to maintain open, constructive, and proactive communication with its partners, local communities, authorities, aviation organizations, and other stakeholders in relation to reducing the environmental impact of the company's operations.

The company seeks solutions to environmental challenges through cooperation with research and development communities, authorities, and other organizations, at both national and international levels ([54], p. 3).

Environmental management is an integral part of the management system at Avinor. In March 2014, Oslo Airport Gardermoen was certified with the EN-NS ISO14001: 2004 standard. At present, the airport also holds the common Avinor AS certification, which is in accordance with the ISO standard 14001:2015 [55]. ISO 14001 is a worldwide meta-standard for implementing Environmental Management Systems (EMS) [56-58]. The ISO 14001 certification of Oslo Airport Gardermoen implies that the environmental management system at this airport is measured against an international best practice standard, to which the airport complies [59].

The airport aims to be recognized as a "Green Airport", which is an important strategic objective for Oslo Airport Gardermoen [60]. A "green airport" is one that has minimal impact on the environment and that endeavors to become a carbon-neutral facility in terms of carbon emissions, to ultimately producing zero greenhouse gas emissions [61]. The concept of a "green airport" is that the airport is a center of sustainable practices [62]. The "Green Airport" strategic objective of Oslo Airport Gardermoen involves an improvement in its performance and understanding the mechanisms that influence the airport's reputation in the context of the environment. In addition, the airport envisages that, through the change of infrastructure and processes, it would be able to reduce its environmental impact through continuous improvement, innovative solutions, and focus on the most effective measures. Furthermore, the airport envisages having open and active communication with all the stakeholders, which would further strengthen the airport's reputation in the context of the environment [60].

\subsection{Regulatory Approvals from Norwegian Environmental Agencies}

The operations at Oslo Airport Gardermoen are subject to stringent environmental regulations [63] established by the Norwegian Environment Agency and the Norwegian Water Resources and Energy Directorate (NVE). Oslo Airport Gardermoen has also been granted a discharge permit, which regulates all discharges, including those of de-icing chemicals. The conditions specify that the operations from the airport should not have a permanent impact on the groundwater resources or waterways surrounding the airport. In this context, Oslo Airport Gardermoen has implemented a comprehensive inspection and monitoring program, which involves monitoring the chemicals used for the aircraft and runway de-icing. The airport also monitors the previous impacts on the groundwater and soil in certain places within the airport, which had occurred due to activities predating the construction of the airport, particularly the military activities and activities that occurred during the Second World War. Furthermore, the fire-fighting foam used for fire drills at 
the airport contains fluorinated compounds, including the hazardous substance PFOS. Therefore, water and soil contamination at the fire training field has been mapped, and an action plan was prepared in 2014 to assess the potential measures [64].

\subsection{Ground Water at Oslo Airport Gardermoen}

Oslo Airport is positioned on the Gardermoen aquifer, which is the largest rain-fed unconfined aquifer in Norway $[65,66]$. The entire groundwater reservoir in Romerike has an area of approximately $100 \mathrm{~km}^{2}$. The airport is positioned over a tenth of the area of this reservoir. Nearly half of the eastern runway in the north impacts a part of the groundwater reservoir. The groundwater reservoir could serve as a source of drinking water at the airport in the future [64]. Avinor AS [64] observed that "the water in the entire groundwater reservoir was high in mineral content and low in oxygen". This was principally caused by the natural dissolution of minerals (particularly calcium, iron, and manganese) occurring in the gravel deposits at the airport. As a consequence, the groundwater at the airport region does not meet the regulatory requirements for drinking water [64].

Surface water is usually processed locally at the airport [67]. The periods during snowmelt and those following heavy rains present an increased risk of groundwater pollution as the airport operations are at the highest during these times [65]. In the case of major run-offs occurring at the airport, particularly during snow-smelts, there occurs a certain influx of unprocessed surface water from the west runway, which then enters the Sogna river. The first meltwater contains a significant quantity of de-icing chemicals, and this water is collected and treated at the airport. The Gardermoen treatment plant processes the wastewater, including the de-icing run-off (containing glycol and formate) [67].

Surface water from the airport's fire training field contains the fire-fighting agents (foam and powder) and jet fuel residuals. This water is also collected by the airport and passed through an oil/water separator, which then connects to the municipal sewage network for further processing of the wastewater ([60], p.7).

\subsection{Annual Water Consumption at Oslo Airport Gardermoen}

The annual water consumption (cubic meters) at Oslo Airport Gardermoen and the year-on-year change \% for the period between 2005 and 2020 are presented in Figure 3. An overall upward trend was observed in the water consumption at Oslo Airport Gardermoen, as evidenced by the year-onyear percentage change line graph, which is more positive than negative, i.e., more values are above the line than below. The annual water consumption at the airport increased from 159,000 cubic meters in 2005 to 277000 cubic meters in 2017. In 2020, a pronounced decline occurred in water consumption, which declined by $46.46 \%$ from the levels of 2019 . As noted earlier, there was a significant downturn in passenger traffic and aircraft movements at the airport in 2020. In addition, a significant decrease was observed for the year 2010, when the airport's annual water consumption decreased by $21.94 \%$ compared to the levels of the year 2009 . The most significant annual increase in water consumption occurred in 2017 , when the annual water consumption increased by $25.33 \%$ relative to the levels of the previous year (Figure 3). A pronounced spike in water consumption had also occurred in 2009 when the consumption increased by $23.43 \%$ relative to the levels of the year 2008. These increases in the water consumption at the airport over the study period could be 
attributed to the greater passenger traffic and aircraft movements and also to the increased use of water for heating to maintain a warmer atmosphere within the airport during the winter weather conditions [55].

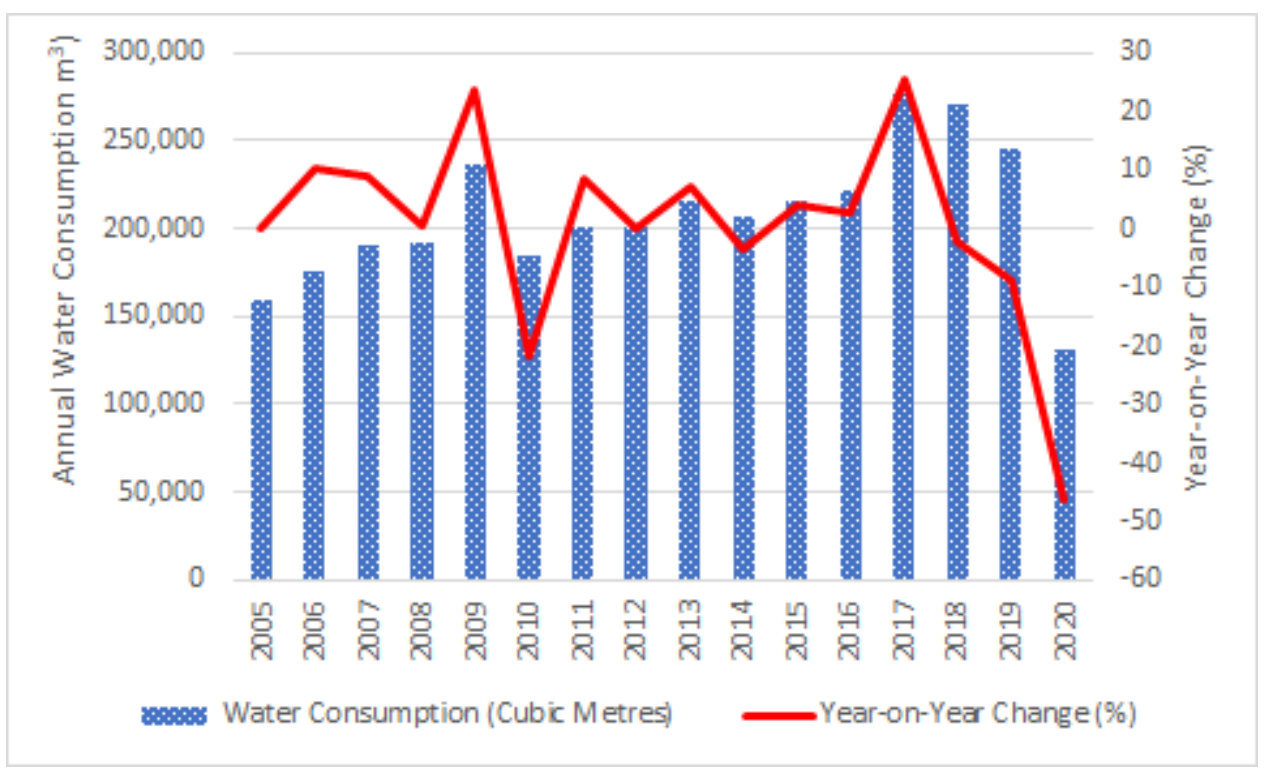

Figure 3 Annual water consumption at Oslo Airport Gardermoen in terms of year-onyear change \% during 2005-2020. Source [55, 67-71].

An important metric used by airports to evaluate their water management is the annual water consumption per enplaned passenger [72]. One enplaned passenger is a measure of the embarkation of a revenue passenger, whether originating, stop-over, connecting, or returning [73]. The annual water consumption per enplaned passenger and the year-on-year change $\%$ during 2005-2020 for Oslo Airport Gardermoen is presented in Figure 4. As visible in the figure, there were four discernible trends in the annual water consumption per enplaned passenger. In the period between 2005 and 2010, the annual water consumption per enplaned passenger remained relatively constant in the range of 9.9-10 liters per enplaned passenger. In 2009, this metric exhibited a pronounced increase of $31.3 \%$ compared to the levels of 2008 , while the general trend during 2009-2016 was downward. In 2016, the annual water consumption per enplaned passenger decreased from the 2009 levels of 13 liters per enplaned passenger to just 8 liters per enplaned passenger. However, the largest single decrease in the annual water consumption per enplaned passenger occurred in 2010, when the metric value declined by $26.2 \%$ (Figure 4). Afterward, the annual water consumption per enplaned passenger increased again, from 8 liters per enplaned passenger in 2016 to 9.7 liters per enplaned passenger in 2018. The year 2017 recorded a significant increase in the annual water consumption per enplaned passenger by $21.3 \%$ compared to the 2016 levels. Another pronounced increase in the annual water consumption per enplaned passenger occurred in 2020, when the metric value increased by $69.8 \%$ compared to the 2019 levels. When the present study was conducted, the cause underlying this significant increase in the water consumption per enplaned passenger in 2020 had not been deciphered. In summary, as revealed by Figure 4, the annual water consumption per enplaned passenger at Oslo Airport Gardermoen varied with time, which was attributed to the changing water requirements of the passengers. 


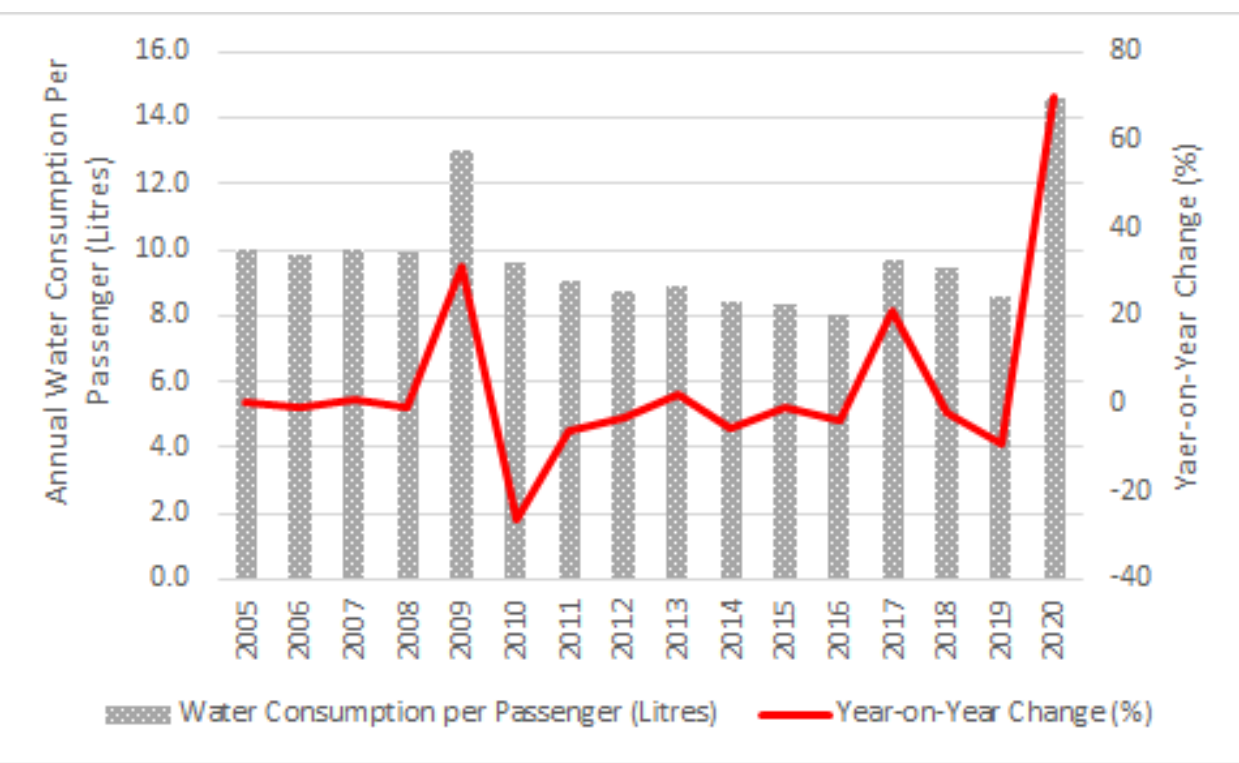

Figure 4 Annual water consumption per enplaned passenger and the year-on-year change $\%$ during 2005-2020. Source [55, 67-71].

Another airport environment-related metric used at airports is the annual water consumption (cubic meter) per aircraft movement [8]. Figure 5 presents the annual water consumption per aircraft movement and the year-on-year change \% during 2005-2020 for Oslo Airport Gardermoen. It was observed that throughout the study period, there had largely been an increase in the water consumption per aircraft movement at Oslo Airport Gardermoen. This was evidenced by the yearon-year percentage change line graph, which was more positive than negative, i.e., more values were above the line than below. As presented in Figure 5, the annual water consumption (cubic meter) per aircraft movement increased from a low of 0.82 cubic meters per aircraft movement in 2005 to a high of 1.13 cubic meters per aircraft movement in 2020 . When the present study was conducted, the cause underlying this significant increase in the water consumption per enplaned passenger in 2020 could not be identified. The largest single annual increase in this metric was recorded for the year 2009 , when the metric increased by $34.93 \%$ compared to the 2008 levels. In 2017 , a pronounced increase of $22.58 \%$ relative to the levels of 2016 occurred in this metric. On the other hand, the largest single annual decrease in the water per aircraft movement occurred in 2010, when this metric decreased by $18.18 \%$ compared to the 2009 levels (Figure 5). It is noteworthy that during the study period, the airlines serving at Oslo Airport Gardermoen increased the size of the aircraft types deployed on their services to the airport. These larger aircraft types included the Airbus A350-900XWB, Boeing 787-9, and Boeing 777-300ER. 


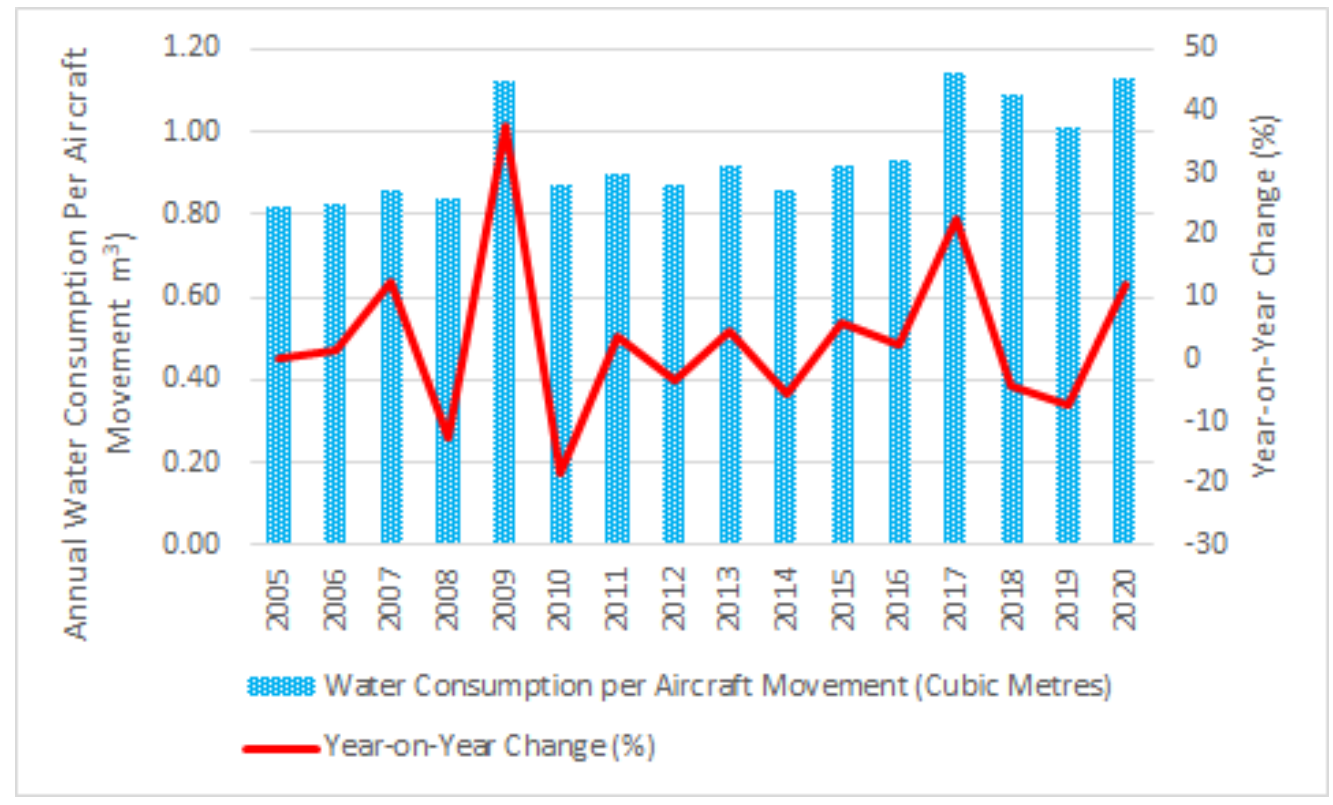

Figure 5 Annual water consumption per aircraft movement and the year-on-year change \% during 2005-2020. Source [53, 68-70].

\subsection{Wastewater at Oslo Airport Gardermoen}

Airports produce wastewater in substantial volumes $[6,8,74]$. According to the definition provided by Allenby and Park ([75], p. 462), wastewater is the "water that carries wastes from homes, businesses, and industries, and usually contains dissolved solids and/or suspended solids". The annual wastewater volume at Oslo Airport Gardermoen and the corresponding year-on-year change \% during 2005-2020 are presented in Figure 6. In general, the annual wastewater volume produced at Oslo Airport Gardermoen exhibited an upward trend during the study period. This was evidenced by the year-on-year percentage change line graph, which was more positive than negative, i.e., more values were above the line than below. As presented in Figure 6, the annual wastewater volume increased from a low of 227,000 cubic meters in 2005 to a high of 341,000 cubic meters in 2018. In 2020, however, a significant decrease of $52.67 \%$ was recorded in the airport's wastewater volume compared to the levels in 2019. This could be attributed to the lower level of activity at the airport in 2020 due to the pandemic restrictions. On the other hand, the largest single annual increase in this metric occurred in 2017 , when the metric value increased by $13.46 \%$. As noted earlier, the air traffic and aircraft movements at the airport demonstrated an overall upward trend during the study period, which could be considered the reason behind the higher levels of wastewater generated at the airport. Oslo Airport Gardermoen monitors the environmental condition of the waterways located in its vicinity several times each year [64]. 


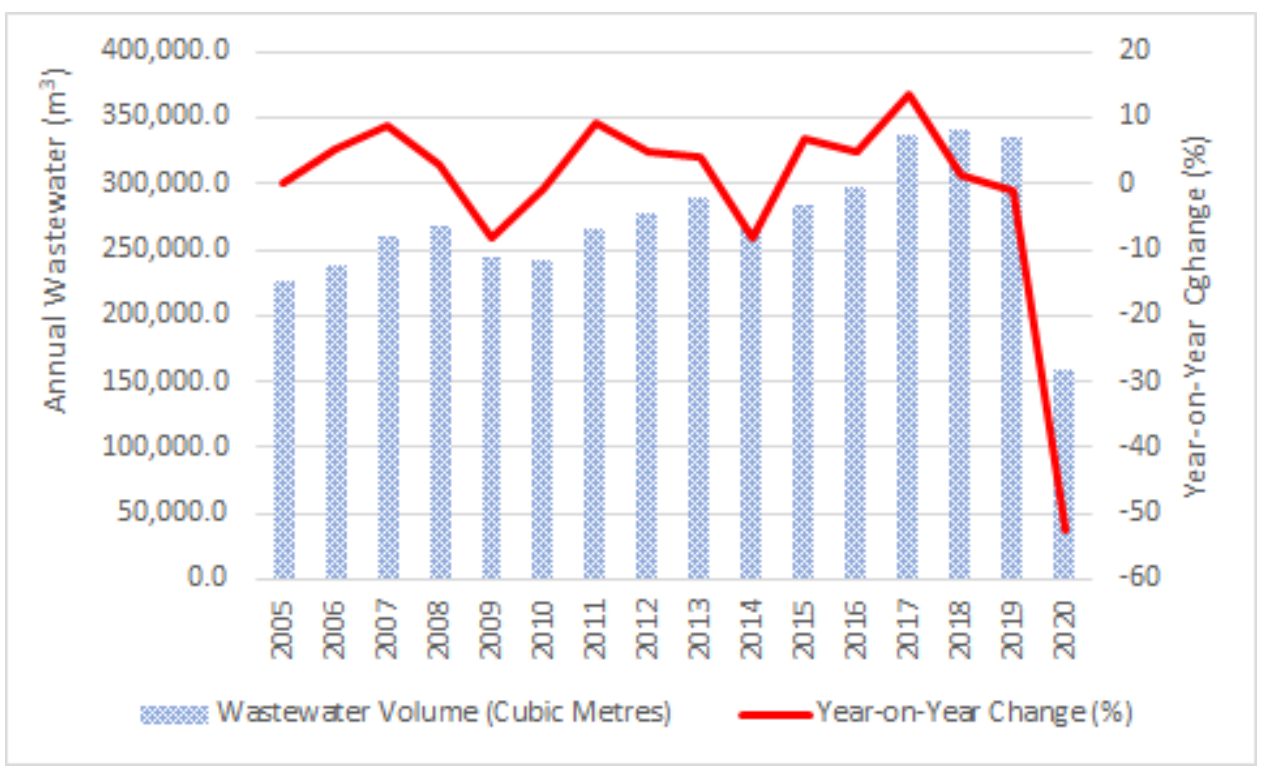

Figure 6 Annual wastewater volume at Oslo Airport Gardermoen and the year-on-year change \% during 2005-2020. Source [53, 68-70].

Figure 7 presents the annual volume of drainage waters generated at Oslo Airport Gardermoen and the year-on-year change \% during 2005-2020. It was observed that the annual volume of the drainage waters produced at the Oslo Airport Gardermoen oscillated remarkably throughout the study period, reflecting varying drainage patterns at the airport. The largest single annual increase in this metric was recorded in 2020, when the airport's drainage waters increased by $31.66 \%$ in volume compared to the previous year. Pronounced increases in the annual volume of the drainage waters produced occurred three times - in 2006 (+20.26\%), $2008(+18.88 \%)$, and $2014(+30.50 \%)$. On the other hand, two significant decreases occurred in the annual volume of the drainage waters produced at the airport. The first one was in 2013 , when this volume decreased by $22.69 \%$ relative to the 2012 levels, and the other was in 2017, when this volume declined by $-22.78 \%$ compared to the 2016 levels. There could be multiple factors driving this increase in the drainage water volume, including changes in the precipitation patterns or climate extremes, change in the land usage policy in favor of allowing less infiltration and higher levels of water run-off, and land subsidence that increased the water volume drained from the soil [76-78]. Storms also have a major impact on the volume of drainage waters generated at airports [79]. In addition, airports are susceptible to flooding, which exerts a significant impact on the drainage system of the airport [80]. 


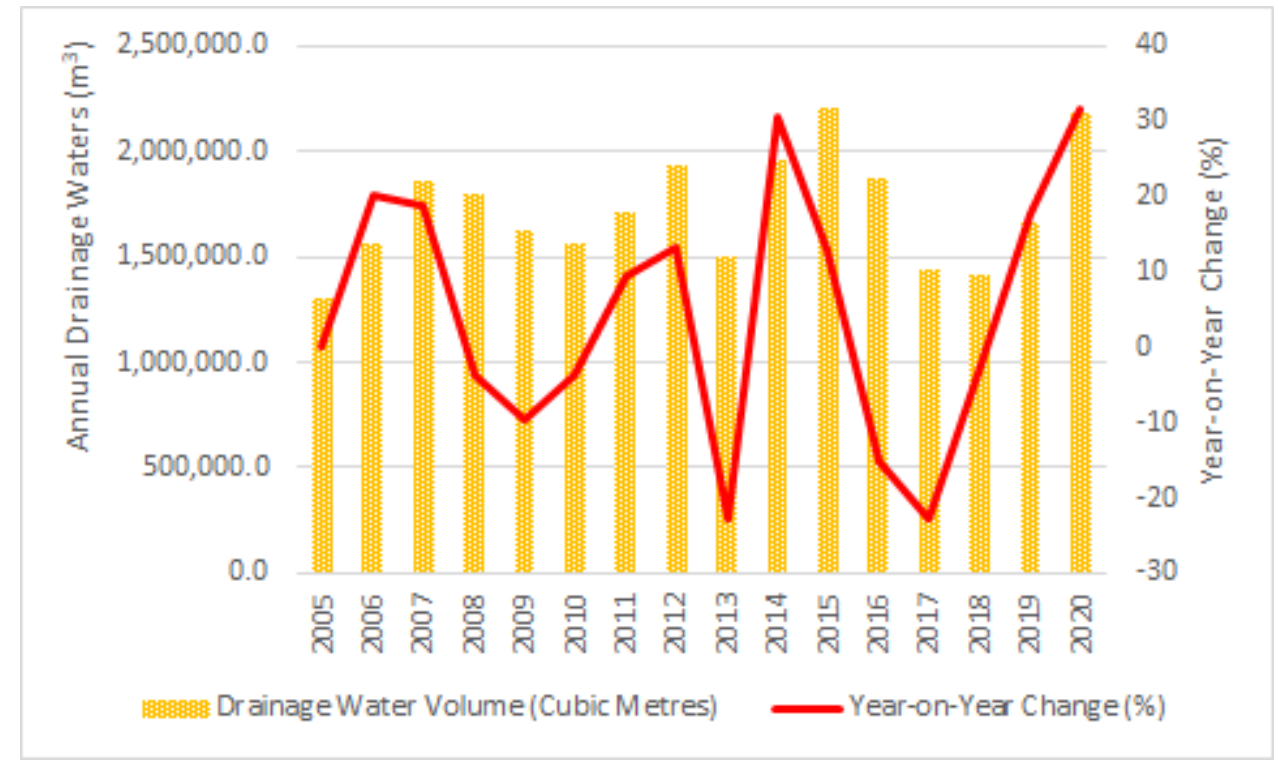

Figure 7 Annual volume of drainage waters at Oslo Airport Gardermoen and the yearon-year change \% during 2005-2020. Source [53, 68-70].

According to Culberson ([12], p. 732), “airport construction and operation could directly or indirectly affect water resources via physical impacts on surface water resources (streams, rivers, and lakes) or wetlands, effects on the quality of surface water and groundwater, and increase in the quantity of stormwater". In the study period of the present work, several major construction projects were undertaken at Oslo Airport Gardermoen. The size of the Terminal 2 of the airport was increased through an extension of its existing terminal, which enabled passengers to navigate using only one terminal. The proposal for the construction of this new terminal was accepted by the Norwegian authorities in February 2009, and the expansion project commenced in 2011. As part of the Terminal 2 expansion project, a new $550 \mathrm{~m}^{2}$ extension of the airport's terminal was opened for the public in June 2011 [81], while the new terminal was opened in April 2017. The new passenger terminal was constructed west of the existing terminal building, covering an area of $117,000 \mathrm{~m}^{2}$. A new triangular-shaped pier referred to as 'Pier B' or the 'North Pier' was constructed north of the existing terminal building over a floor area of 63,000 $\mathrm{m}^{2}$ [48]. In 2018, work on the airside part of the terminal at Oslo Airport was commenced, and this project is due for completion in the second quarter of 2022 [82]. Drainage is a fundamental part of any construction and is essential for the removal of surface and sub-surface water during the construction process [83]. Therefore, it is possible that the drainage waters at Oslo Airport Gardermoen were affected by the construction works being conducted at the airport.

\subsection{Sustainable Water Management at Oslo Airport Gardermoen}

The heating system of the buildings at Oslo Airport Gardermoen utilizes greywater and groundwater under the airport land [84, 85]. The surface water at the airport is typically handled locally at the airport facilities. In the case of major run-offs, which occur mostly during snowmelts, there is a certain influx of unprocessed surface water from the west runway to the Sogna river. The treatment of the wastewater and a portion of the collected de-icing chemicals (glycol and formate) used for de-icing the aircraft and the runways during the winter period is performed at the 
Gardermoen treatment plant. The excess groundwater is either released back into the Sogna river or is re-infiltrated [70]. The surface water that is used in the fire-drill field at Oslo Airport Gardermoen is collected and subsequently passed through an oil separator to be sent to the municipal sewer system. This water potentially contains residuals of the jet fuel that is used in the fire drills conducted at the airport [67]. In addition, the snow that is collected at Oslo Airport Gardermoen during the winter period is stored and later used for cooling the terminal building in the summer months [85]. Moreover, collection systems have been installed at Oslo Airport Gardermoen for capturing excess water and de-icing chemicals from the three de-icing platforms alongside the taxiways and at the beginning of the runways. In summary, sustainable water management at Oslo Airport Gardermoen is achieved using the airport infrastructure and the various technologies for treating surface water and groundwater at the Gardermoen treatment plant, which is further supplemented by the airport's collection systems for de-icing agents that assist in preventing contamination of the water resources.

\section{Conclusions}

Sustainable water management has become a key objective for airports throughout the world as airports consume huge amounts of water and produce waste and drainage waters in great quantities. In this context, the present study was aimed to empirically examine the annual water consumption at Oslo Airport Gardermoen, which is Norway's largest airport and a major Scandinavian hub airport. The case study analysis revealed that the airport's annual water consumption increased yearly throughout the study period. Specifically, the annual water consumption increased from 159,000 cubic meters in 2005 to 277,000 cubic meters in 2017. However, in the later years (2018 to 2020) of the study period, the annual water consumption exhibited a general downward trend, with the lowest annual consumption recorded in the year 2020 (131,700 cubic meters). The annual water consumption per enplaned passenger was observed to fluctuate during the study period. While the lowest annual water consumption per enplaned passenger occurred in 2016 (8 liters per passenger), the highest annual water consumption per enplaned passenger was recorded in 2020 (14.6 liters per passenger). Furthermore, the water consumption per aircraft movement at Oslo Airport Gardermoen largely increased during the study period. The water consumption per aircraft movement increased from a low of 0.82 cubic meters per aircraft movement in 2005 to a high of 1.13 cubic meters per aircraft movement in 2020 . This was attributed to the dramatic increase in aircraft movements during the study period. In addition, during the study period, the airlines had deployed larger aircraft types, which also influenced the water consumption patterns at the airport.

The case study also revealed that the annual wastewater volume at Oslo Airport Gardermoen generally exhibited an upward trend during the study period. The annual wastewater volume increased from 227,000 cubic meters in 2005 to 341,000 cubic meters in 2018. However, the year 2020 witnessed a huge significant decrease in the wastewater volume, which decreased by $52.67 \%$ relative to the 2019 levels. Moreover, the annual volume of drainage waters Oslo Airport Gardermoen fluctuated remarkably during the study period, reflecting varying drainage patterns at the airport. While the lowest annual volume of drainage waters was recorded in $2005(1,303,000$ cubic meters), the highest annual volume of drainage waters was recorded in 2015 (2,205,000 cubic meters). 
Similar to the other airports around the world, Oslo Airport Gardermoen has implemented various strategies and practices for sustainable water management, which underpin its water management. These practices include using greywater and groundwater for heating the building at the airport. The surface water at Oslo Airport Gardermoen is generally handled locally at the airport facilities. As another measure, the excess groundwater at Oslo Airport Gardermoen is either released back into the Sogna river or is re-infiltrated. Moreover, the surface water that is used in the fire-drill field at Oslo Airport Gardermoen is collected and subsequently passed through an oil separator to be sent to the local municipal sewer system for further processing. Sustainable airport water management requires the use of infrastructure and various technologies such as water processing plants and systems for capturing chemicals and aircraft de-icing agents that could potentially contaminate the water resources. Oslo Airport Gardermoen has installed and implemented the use of such infrastructure.

As with all research, the present study also has certain limitations. One limitation of the present study was that the annual water volume data for Oslo Airport Gardermoen was aggregated at the airport level, because of which it was not possible to examine the annual trends of water consumption in the offices and buildings of the airport. Further, it was not possible to assess the amount of treated water that was used for aircraft de-icing operations. If these data are available in the future, a subsequent study could be conducted to analyze these trends. Another limitation of the present study was that it was restricted to a single site, i.e., Oslo Airport Gardermoen. In the future, a cross-sectional study could be conducted to compare Oslo Airport Gardermoen with other airports across the world in terms of sustainable water management. This would enable a greater understanding of how different regions across the world are addressing the issue of sustainable water management at airports.

\section{Author Contributions}

The author did all the research work of this study.

\section{Competing Interests}

The author has declared that no competing interests exist.

\section{References}

1. Baxter G, Srisaeng P, Wild G. An assessment of airport sustainability, part 2-Energy management at Copenhagen airport. Resources. 2018; 7: 32.

2. Jarach D. Airport marketing: Strategies to cope with the new millennium. Abingdon: Routledge; 2017.

3. Carvalho Cl, Calijuri ML, Assemany PP, Silva MD, Neto RF, Santiago AF, et al. Sustainable airport environments: A review of water conservation practices in airports. Resour Conserv Recy. 2013; 74; 27-36.

4. Neto RF, Calijuri ML, Carvalho $\mathrm{Cl}$, Santiago AF. Rainwater treatment in airports using slow sand filtration followed by chlorination: Efficiency and costs. Resour Conserv Recy. 2012; 65: 124129. 
5. Cremer I, Rice S. Which emotions mediate the relationship between type of water recycling projects and likelihood of using green airports? Int J Sustain Aviat. 2016; 1: 299-313.

6. Baxter G, Srisaeng P, Wild G. An assessment of sustainable airport water management: The case of Osaka's Kansai international airport. Infrastructures. 2018; 3: 54.

7. Somerville A, Baxter GS, Richardson S, Wild G. Sustainable water management at Australian regional airports: The case of Mildura airport. Aviation. 2015; 19: 83-89.

8. Baxter G, Srisaeng P, Wild G. An assessment of airport sustainability: Part 3-Water management at Copenhagen airport. Resources. 2019; 8: 135.

9. Meincke P, Tkotz A. Airports-types, functions, facilities and accessibility. In: Introduction to aviation management. Münster: LIT Verlag; 2010.

10. Thomas C, Hooper P. Sustainable development and environmental capacity of airports. In: Airport operations. 3rd ed. New York: McGraw-Hill; 2013.

11. Vanker S, Enneveer M, Mäsak M. Implementation of environmentally friendly measures at Tallinn airport. Aviation. 2013; 17: 14-21.

12. Culberson SD. Environmental impact of airports. In: Airport engineering: Planning, design, and development of 21st century airports. 4th ed. Hoboken: John Wiley \& Sons; 2011. pp.704-738.

13. Grantham DJ. Surface water contamination caused by airport operations. In: Environmental management at airports: Liabilities and social responsibilities. London: Thomas Telford; 1996. pp.104-120.

14. Fawell JK. Drinking water quality and health. In: Pollution: Causes, effects and control. 5th ed. London: Royal Society of Chemistry; 2015.

15. Kazda T, Caves B, Kamenický M. Environmental control. In: Airport design and operation. 3rd ed. Bingley: Emerald Group Publishing; 2015. pp. 503-539.

16. Dimitriou DJ, Voskaki AJ. Regional airports' environmental management: Key messages from the evaluation of ten European airports. In: Regional airports. Southampton: WIT Press; 2011.

17. Rossi G, Cancelliere A. Managing drought risk in water supply systems in Europe: A review. Int J Water Resour Dev. 2013; 29: 272-289.

18. Chen Z, Ngo HH, Guo W. A critical review on sustainability assessment of recycled water schemes. Sci Total Environ. 2012; 426: 13-31.

19. Yu ZL, Rahardianto A, DeShazo JR, Stenstrom MK, Cohen Y. Critical review regulatory incentives and impediments for onsite graywater reuse in the United States. Water Environ Res. 2013; 85: 650-662.

20. Gupta AD, Onta PR. Sustainable groundwater resources development. Hydrol Sci J. 1997; 42: 565-582.

21. Boyle T, Giurco D, Mukheibir P, Liu A, Moy C, White S, et al. Intelligent metering for urban water: A review. Water. 2013; 5: 1052-1081.

22. Bartram J, Balance R. Water quality monitoring: A practical guide to the design and implementation of freshwater quality studies and monitoring programmes. Boca Raton: CRC Press; 1996.

23. Couto EA, Calijuri ML, Assemany PP, Santiago AF, Lopes LS. Greywater treatment in airports using anaerobic filter followed by UV disinfection: An efficient and low-cost alternative. J Clean Prod. 2015; 106: 372-379.

24. Derrington ML. Qualitative longitudinal methods: Researching, implementation and change. Thousand Oaks: SAGE Publications; 2019. 
25. Hassett ME, Paavilainen-Mäntymäki E. Longitudinal research in organizations: An introduction. In: Handbook of longitudinal research methods in organisation and business studies. Cheltenham: Edward Elgar Publishing; 2013. pp.1-22.

26. Neale B. What is qualitative longitudinal research? London: Bloomsbury Academic; 2016.

27. Kalaian A, Kasim M. Longitudinal studies. In: Encyclopaedia of survey research methods. Thousand Oaks: SAGE Publications; 2008. pp.440-441.

28. Remenyi D, Williams B, Money A, Swartz E. Doing research in business and management: An introduction to process and method. London: SAGE Publications; 2010.

29. Yin RK. Case study research and applications: Design and methods. Los Angeles: SAGE Publications; 2018.

30. Ang SH. Research design for business \& management. London: SAGE Publications; 2014.

31. McCutchen DM, Meredith JR. Conducting case study research in operations management. J Oper Manag. 1993; 11: 239-256.

32. Grant A. Doing excellent social research with documents: Practical examples and guidance for qualitative researchers. Abingdon: Routledge; 2019.

33. Oates BJ. Researching information systems and computing. London: SAGE Publications; 2006.

34. Gil-Garcia JR. Enacting electronic government success: An integrative study of governmentwide websites, organizational capabilities, and institutions. New York: Springer Science+Business Media; 2012.

35. Woods AM, Graber KC. Interpretive and critical research: A view through the qualitative lens. In: Routledge handbook of physical education pedagogies. Abingdon: Routledge; 2016.

36. Olson M. Document analysis. In: Encyclopaedia of case study research, Volume 1 . Thousand Oaks: SAGE Publications; 2010.

37. Scott J. Documents, types of. In: The SAGE encyclopaedia of social science research methods. Thousand Oaks: SAGE Publications; 2004.

38. Scott J. A dictionary of sociology. 4th ed. Oxford: Oxford University Press; 2014.

39. Scott J, Marshall G. A dictionary of sociology. 3rd ed. Oxford: Oxford University Press; 2009.

40. O'Leary Z. The essential guide to doing research. London: SAGE Publications; 2004.

41. Baxter G. Achieving carbon neutral airport operations by 2025: The case of Sydney airport, Australia. Transp Telecommun. 2021; 22: 1-14.

42. Feldman J. 25 years to life. Air Transp World. 1998; 35: 91-96.

43. latrou K, Williams G. New for old: An analysis of the impact of the new Athens and Oslo airports. J Air Transp Manag. 2008; 2: 235-248.

44. Lian Jl. Network dependency and airline competition - Consequences for remote areas in Norway. J Air Transp Manag. 2010; 16: 137-143.

45. Bråthen S, Fuglum K. Developing airports in a long-term perspective: The case of Troms $\varnothing$, Norway. In: Air transport provision in remoter regions. Abingdon: Routledge; 2016.

46. International Airport Review. Oslo airport - Europe's most efficient airport [Internet]. Kent: International Airport Review; 2010. Available from: https://www.internationalairportreview.com/article/3989/oslo-airport-europes-mostefficient-airport/.

47. Avinor AS. About Oslo airport: Facts and figures [Internet]. Oslo: Avinor AS; 2021. Available from: https://avinor.no/en/corporate/airport/oslo/about-us/about-oslo-airport/tall-og-fakta. 
48. Avinor AS. The new Oslo airport 2017 [Internet]. Oslo: Avinor AS; 2017. Available from: https://avinor.no/en/corporate/airport/oslo/development/this-is-new/this-is-new.

49. Airport Technology. Oslo airport terminal 2 [Internet]. New York: Airport Technology; 2017. Available from: https://www.airport-technology.com/projects/oslo-airport-terminal-2/.

50. Dube K, Nhamo G, Chikodzi D. COVID-19 pandemic and prospects for recovery of the global aviation industry. J Air Transp Manag. 2021; 92: 102022.

51. Sobieralski JB. COVID-19 and airline employment: Insights from historical uncertainty shocks to the industry. Transp Res Interdiscip Perspect. 2021; 5: 100123.

52. lacus SM, Natale F, Santamaria C, Spyratos S, Vespe M. Estimating and projecting air passenger traffic during the COVID-19 coronavirus outbreak and its socio-economic impact. Safety Sci. 2020; 129: 104791.

53. Avinor AS. About Oslo airport: Traffic statistics [Internet]. Oslo: Avinor AS; 2021. Available from: https://avinor.no/en/corporate/airport/oslo/about-us/traffic statistics/trafikkstatistikk.

54. Avinor AS. The avinor group [Internet]. Oslo: Avinor AS; 2021. Available from: https://avinor.no/en/corporate/about-us/the-avinor-group/about-the-company.

55. Avinor Oslo Airport. Environmental report 2020 [Internet]. Oslo: Avinor AS; 2021. Available from: $\quad$ https://avinor.no/globalassets/ oslo-lufthavn/om-oslo-lufthavn/miljo-oglokalsamfunn/miljodokumenter/miljoarsrapport-2020-engelsk.pdf.

56. Heras-Saizarbitoria I, Landín GA, Molina-Azorín JF. Do drivers matter for the benefits of ISO 14001? Int J Oper Prod Manag. 2011; 31: 192-216.

57. Heras-Saizarbitoria I, Boiral O, Arana G. Renewing environmental certification in times of crisis. J Clean Prod. 2016; 115: 214-223.

58. Hikichi SE, Salgado EG, Beijo LA. Forecasting number of ISO 14001 certifications in the Americas using ARIMA models. J Clean Prod. 2017; 147: 242-253.

59. Vestvik-Lunde J. Oslo airport achieves environmental management certification [Internet]. Bærum: Det Norske Veritas Group; 2014. Available from: https://www.dnvgl.com/news/osloairport-achieves-environmental-management-certification--7403.

60. Avinor Oslo Airport. Environmental report 2019 [Internet]. Oslo: Avinor AS; 2020. Available from: $\quad$ https://avinor.no/globalassets/ oslo-lufthavn/om-oslo-lufthavn/miljo-oglokalsamfunn/miljodokumenter/environmental-report-2019.pdf.

61. González-Ruiz JD, Duque E, Restrepo J. Green airport infrastructure in Colombia: Opportunities for public-private partnerships schemes. Pertanika J Sci Technol. 2017; 25: 37-46.

62. Sumathi N, Phanendra MG, Teja KG. Green airports - Solution to stop pollution! Int J Latest Technol Eng Manag Appl Sci. 2018; VII: 78-85.

63. Buyck C. War on winter. Air Transp World. 2002; 39: 15-17.

64. Avinor AS. Water and soil [Internet]. Oslo: Avinor AS; 2021. Available from: https://avinor.no/en/corporate/airport/oslo/community-and-environment/vann-oggrunn/vann-og-grunn.

65. French HK, Hardbattle C, Binley A, Winship P, Jakobsen L. Monitoring snowmelt induced unsaturated flow and transport using electrical resistivity tomography. J Hydrol. 2002; 267: 273284.

66. French HK, Binley A. Snowmelt infiltration: Monitoring temporal and spatial variability using time-lapse electrical resistivity. J Hydrol. 2004; 297: 174-186. 
67. Oslo Lufthavn AS. Environmental report 2015 [Internet]. Oslo: Oslo Lufthavn AS; 2016. Available from:

https://avinor.no/globalassets/ oslo-lufthavn/om-oslo-lufthavn/omoss/rapporter/en/environmental/environmental-report-2015.pdf.

68. Oslo Lufthavn AS. Environmental report 2013 [Internet]. Oslo: Oslo Lufthavn AS; 2014. Available from: $\quad$ https://avinor.no/globalassets/_oslo-lufthavn/om-oslo-lufthavn/omoss/rapporter/en/environmental/environmental report 2013.pdf.

69. Oslo Lufthavn AS. Environmental report 2017 [Internet]. Oslo: Oslo Lufthavn AS; 2018. Available from: https://avinor.no/globalassets/ oslo-lufthavn/om-oslo-lufthavn/omoss/rapporter/en/environmental/environmental-report-2017.pdf.

70. Oslo Lufthavn AS. Environmental report 2007 [Internet]. Oslo: Oslo Lufthavn AS;2008. Available from:

https://avinor.no/globalassets/ oslo-lufthavn/om-oslo-lufthavn/omoss/rapporter/en/environmental/environmental-report-2007.pdf.

71. Oslo Lufthavn AS. Environmental report 2010 [Internet]. Oslo: Oslo Lufthavn AS; 2011. Available from:

https://avinor.no/globalassets/ oslo-lufthavn/om-oslo-lufthavn/omoss/rapporter/en/environmental/Environmental-report-2010.pdf.

72. Graham A. Airport benchmarking: A review of the current situation. Benchmarking. 2005; 12: 99-111.

73. Holloway S. Straight and level: Practical airline economics. 3rd ed. Abingdon: Routledge; 2016.

74. Pitt M, Brown A, Smith A. Waste management at airports. Facilities. 2002; 20: 198-207.

75. Allenby M, Park C. A dictionary of environment and conservation. Oxford: Oxford University Press; 2013.

76. Giambastiani BM, Macciocca VR, Molducci M, Antonellini M. Factors affecting water drainage long-time series in the salinized low-lying coastal area of Ravenna (Italy). Water. 2020; 12: 256.

77. Essink GO, Kooi H. Land-subsidence and sea-level rise threaten fresh water resources in the coastal groundwater system of the Rijnland water board, the Netherlands. In: Climate change effects on groundwater resources: A global synthesis of findings and recommendations. Boca Raton: CRC Press; 2012. pp.227-248.

78. Pauw P, Louw PG, Essink GH. Groundwater salinization in the Wadden Sea area of the Netherlands: Quantifying the effects of climate change, sea level rise and anthropogenic interferences. Neth J Geosci. 2012; 91: 373-383.

79. US Department of Transportation Federal Aviation Administration. Unified facilities criteria (UFC): Surface drainage design [Internet]. Washington DC: FAA; 2006. Available from: https://www.faa.gov/documentLibrary/media/Advisory Circular/150 5320 5d.pdf.

80. International Civil Aviation Organization. Water management at airports [Internet]. Montreal: ICAO; 2019. Available from: https://www.icao.int/environmentalprotection/Documents/Water\%20management\%20at\%20airports.pdf.

81. Airport Technology. Gardermoen airport (GEN/ENGM), Oslo [Internet]. New York: Airport Technology; 2021. Available from: $\underline{\text { https://www.airport- }}$ technology.com/projects/gardermoen_as/.

82. Jarvis H. Construction time again for Oslo airport [Internet]. Hobro: STANDBY Nordic; 2018. Available from: https://standbynordic.com/major-construction-again-for-oslo-airport/.

83. ACO Pty Ltd. A fundamental but often forgotten part of construction: Drainage [Internet]. Emu Plains, NSW: ACO Pty Ltd; 2021. Available from: https://www.acodrain.com.au/fundamentalconstruction-drainage/. 
84. Airport Technology. Sustainable success: Oslo airport opens 'world's greenest' terminal [Internet]. New York: Airport Technology; 2017. Available from: https://www.airporttechnology.com/features/featuresustainable-success-oslo-airport-opens-worlds-greenestterminal-5885304/.

85. Leonard D, Nicholson I. How to make airports sustainable and reduce the environmental impact [Internet]. Kent: International Airport Review; 2020. Available from: https://www.internationalairportreview.com/article/119281/how-make-airports-sustainable/.

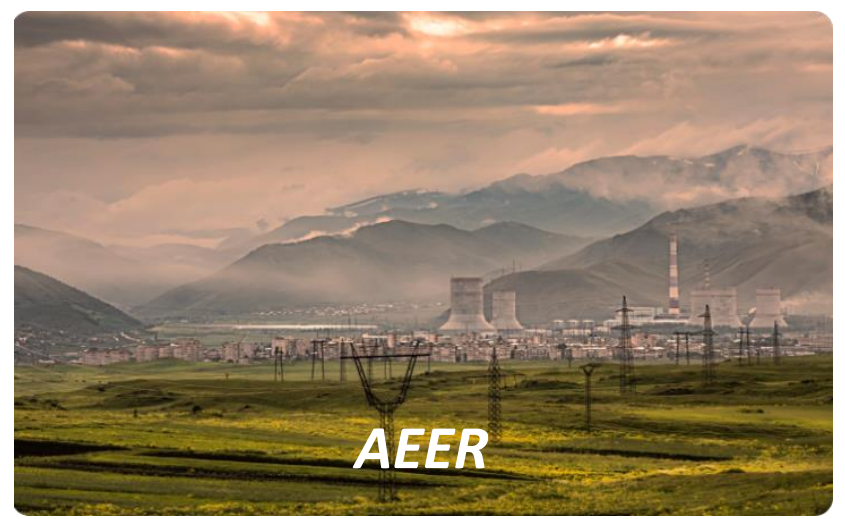

Enjoy AEER by:

1. Submitting a manuscript

2. Joining in volunteer reviewer bank

3. Joining Editorial Board

4. Guest editing a special issue

For more details, please visit:

http://www.lidsen.com/journals/aeer 